\title{
La Revolución Capitalista de Chile (1973-2003) Manuel Gárate Chateau
}

\author{
Ediciones Universidad Alberto Hurtado, Santiago, 2012, 589 págs. \\ Antonio Elizalde Hevia \\ Universidad Bolivariana, Santiago, Chile. Email: aelizalde@ubolivariana.cl
}

El autor de este libro plantea varias interrogantes de enorme importancia para entender la historia reciente de nuestro país. ¿Cómo explicar la modernización económica de Chile durante la dictadura militar? ¿Cómo el liberalismo económico se instaló en nuestro país antes de la caída del muro de Berlín y de las experiencias conservadoras de Ronald Reagan y Margaret Thatcher? ¿Cuáles son los fenómenos que permitieron la aceptación de este modelo neoliberal? ¿De qué manera se gestaron las elites económicas durante el último tercio del siglo XX en Chile?

El estudio sobre el modelo económico chileno, especialmente con posterioridad al golpe militar de 1973 no constituye una novedad en sí mismo, debido a que existen numerosos trabajos tanto economistas, sociólogos y cientistas políticos que han tratado el tema. Sin embargo, los historiadores se han mantenido relativamente ausentes del debate por cuestiones metodológicas, pero incluso ideológicas en el sentido epistemológico del término. La llamada Historia del Tiempo Presente (HTP), o incluso sus vertientes más recientes como la Historia Inmediata, concepto surgido en torno los debates respecto a las violaciones de los derechos humanos en el continente latinoamericano, aún no ha logrado romper la barrera que separa a muchos de los investigadores en historia respecto del tiempo cercano. La supuesta búsqueda de una objetividad que entregaría la perspectiva temporal, o bien la anhelada neutralidad de quien escribe fuera de los eventos que le tocó vivir, sigue limitando los análisis históricos en torno al pasado reciente. A lo anterior se agrega la ficticia y exagerada separación de las disciplinas al interior del mundo de las ciencias sociales, las cuales más que crear puntos de encuentro, tienden hacia la híper-especialización y el celo profesional.

Es por esta y otras razones, que nos resulta enriquecedor y desafiante la aparición de un libro que justamente intenta ir más allá de las barreras disciplinarias para intentar construir una interpretación coherente de la transformación económica de Chile durante los últimos 40 años. Para ello, incluso el autor se remonta a los inicios de la República en una suerte de genealogía respecto de los orígenes del pensamiento liberal económico en el país. Esto lo lleva a dedicar no pocas páginas a la cuestión de los precursores del liberalismo económico. Pero este salto temporal, quizás algo exagerado en un principio, se justifica plenamente en el conjunto de la obra, pues de lo que se trata es de comparar si efectivamente el régimen liberal económico de la segunda mitad del siglo XIX chileno se entronca con la transformación neoliberal efectuada en Chile por los tecnócratas de la dictadura militar a partir de la segunda mitad de la década de los setentas. La tarea no es menor, pues implica una ampliación del campo interpretativo que cubre un período cercano a los 200 años. No obstante el grueso de la investigación está dedicada a comprender e interpretar los cambios que vivió el país especialmente a partir de la década de los años 50 del siglo XX, y con especial énfasis tras el golpe militar de 1973.

Siendo un trabajo que corresponde a la adaptación de la tesis de doctorado del autor, contiene evidentemente una hipótesis central: entendiendo como revolución una transformación radical de la sociedad en términos materiales y culturales producto de una intervención política originaria en un período relativamente corto de tiempo y comandaba por una élite ideologizada, entonces la única verdadera revolución vivida por el país sería aquella que se originó con la violencia original del Golpe Estado de 1973, y operada -en la práctica- por la tecnocracia de los economistas chilenos formados principalmente en la Universidad de Chicago. Si bien otros autores han esbozado anteriormente esta idea, ya desde los primeros trabajos de Pilar Vergara, Mario Góngora, Juan Gabriel Valdés, Verónica Valdivia y Julio Pinto, el trabajo de Manuel Gárate se aboca precisamente a justificarla en un marco temporal extendido, utilizando para ello todas las herramientas disponibles en las diferentes disciplinas de las ciencias sociales. Sin embargo, resulta aún más interesante la interpretación sobre el rol de la Concertación y de sus elites tecnocráticas en la 
continuación y consolidación del modelo económico implantado durante la dictadura. Dicho de otro modo, sería la continuación del mismo proceso pero mediante otros medios. Es más, el autor identifica a un grupo de economistas surgidos de CIEPLAN, como los forjadores de la solución de continuidad entre las reformas económicas llevadas a cabo en la dictadura, y la consolidación de los pilares fundamentales del modelo económico de libre mercado, rompiendo algunas de las promesas claves con las cuales se logró el retorno a la democracia, como por ejemplo: la revisión del proceso de privatizaciones de las grandes empresas del Estado, o bien la reforma estructural de los sistemas de salud educación y pensiones heredados del régimen militar. Lógicamente la presencia del ex-dictador como comandante en Jefe del Ejército hasta 1998 justifica parcialmente esta actitud, no explica el actuar y el giro ideológico que vivieron las elites tecnocráticas concertacionistas desde la segunda mitad de la década de los ochentas.

A modo de resumen, podemos decir que este estudio, deudor del relato de los viejos historiadores conectados con su tiempo y con el cuidado en la prosa (Jules Michelet, Ernest Lavisse), trata dos cuestiones fundamentales sobre el pasado reciente de Chile. La primera es la profunda transformación económica y social vivida entre 1970 y 2003 , es decir el período que incluye el régimen militar y los tres primeros gobiernos de la transición democrática. La segunda se refiere a la evolución del pensamiento liberal económico en Chile y el surgimiento de una nueva elite patronal formada la imagen del discurso de los economistas neoclásicos. Para situar la profundidad de los cambios en el país desde 1973, la investigación se remonta a los comienzos del siglo XIX cuando llegan las primeras ideas sobre liberalismo económico, pasando por la década de 1930 cuando se crea el modelo del «Estado de Compromiso». Sin embargo, el análisis está centrado en el origen y desarrollo de los «Chicago Boys» como gestores de la transformación económica del país, entendida como un tipo especial de violencia, y de los importantes cambios producidos al interior de la élite dirigente. Finalmente, el libro aborda los usos del pasado reciente en las estrategias del poder y las representaciones naturalizantes de la nueva elite respecto de los imaginarios de una sociedad articulada en torno al modelo de libre mercado y tensionada por el conservadurismo moral.

En definitiva, la propuesta del autor es que el período 1973-2003 (incluso pudiendo extenderse hasta el gobierno de Michelle Bachelet) constituye un solo gran proceso histórico de transformación radical de la sociedad chilena, probablemente el más profundo e irreversible de toda su historia. Estamos frente a una revolución no sólo política o institucional, sino que gestora de un cambio profundo en la cultura en el sentido común de los chilenos, que sobrepasa el giro estructural en la economía, y que se instala al nivel de las representaciones y de las ideas. El Chile de la sociedad de mercado, del consumo, de la iniciativa privada y del emprendimiento como fetiche, es el resultado de este proceso. Y si bien se observan a nivel global tendencias similares, el autor nos demuestra hasta qué punto Chile constituyó un laboratorio y sino la primera, al menos una de las primeras experiencias de procesos que se han mundializado a partir de la caída del Muro de Berlín.

Vale la pena leer este libro, pues se analizan los 17 años de implantación del modelo económico vigente hasta hoy en Chile, como asimismo su posterior consolidación durante los gobiernos de la Concertación. Pero además se revisan los antecedentes históricos del liberalismo económico en Chile y la forma en que, a partir de 1975, se transformó radicalmente la estructura del Estado y la economía, en una ruptura no sólo con el modelo de desarrollo que el país había llevado adelante durante varias décadas sino que también en un quiebre con la tradición liberal decimonónica. 